University of Wollongong

Research Online

Faculty of Engineering and Information

Faculty of Engineering and Information

Sciences - Papers: Part A

Sciences

$1-1-2014$

\title{
An experimental investigation on the deformation and degradation behaviour of geogrid-reinforced ballast
}

Sd. K Karimullah Hussaini

Indian Institute of Technology-Patna

B Indraratna

University of Wollongong, indra@uow.edu.au

J S. Vinod

University of Wollongong, vinod@uow.edu.au

Follow this and additional works at: https://ro.uow.edu.au/eispapers

Part of the Engineering Commons, and the Science and Technology Studies Commons

Research Online is the open access institutional repository for the University of Wollongong. For further information contact the UOW Library: research-pubs@uow.edu.au 


\title{
An experimental investigation on the deformation and degradation behaviour of geogrid-reinforced ballast
}

\begin{abstract}
Railroad ballast, owing to its unbounded granular nature, spreads laterally when subjected to large vertical axle loads, which influences the track stability. In this view, large-scale cyclic tests have been conducted on ballast to explore the role of geogrid in controlling the lateral deformation of ballast and hence improving the track performance. Fresh latite ballast having a mean particle size of $35 \mathrm{~mm}$ and geogrids with different aperture sizes was used for the investigations. Tests were conducted using a modified process simulation test (MPST) apparatus at a loading frequency of $20 \mathrm{~Hz}$, with geogrid placed at the subballast-ballast interface and within the ballast. The laboratory experimental results indicate that the geogrid arrests the lateral spreading of ballast, reduces the extent of permanent vertical settlement and minimises the particle breakage under high-frequency cyclic loading. However, the improvement in track performance is directly influenced by the effectiveness of the ballast-geogrid interface. It is shown that the higher the shear strength at the ballast-geogrid interface, the lower is the deformation and degradation of ballast. In addition, the geogrid also reduces the extent of vertical stress in the subgrade soil. These test results highlight the role of geogrid in stabilising the ballast thus encouraging its use as track reinforcement in railway applications.
\end{abstract}

\section{Keywords}

reinforced, experimental, geogrid, behaviour, ballast, degradation, deformation, investigation

\section{Disciplines \\ Engineering | Science and Technology Studies}

\section{Publication Details}

Hussaini, S., Indraratna, B. \& Vinod, J. (2014). An experimental investigation on the deformation and degradation behaviour of geogrid-reinforced ballast. Second International Conference on Railway Technology: Research, Development and Maintenance (pp. 1-12). Scotland: Civil-Comp Press. 


\title{
An Experimental Investigation on the Deformation and Degradation Behaviour of Geogrid-Reinforced Ballast
}

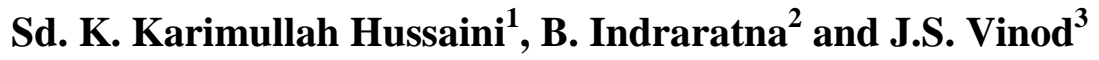 \\ ${ }^{1}$ Department of Civil and Environmental Engineering \\ Indian Institute of Technology Patna, Bihar, India \\ ${ }^{2}$ Faculty of Engineering and Information Sciences \\ Centre for Geomechanics and Railway Engineering \\ University of Wollongong, Australia \\ ${ }^{3}$ Faculty of Engineering and Information Sciences \\ School of Civil, Mining and Environmental Engineering \\ University of Wollongong, Australia
}

\begin{abstract}
Railroad ballast owing to its unbounded granular nature spreads laterally when subjected to large vertical axle loads, which influences the track stability. In this view, large-scale cyclic tests have been conducted on ballast to explore the role of geogrid in controlling the lateral deformation of ballast and hence improving the track performance. Fresh latite ballast having a mean particle size of $35 \mathrm{~mm}$ and geogrids with different aperture sizes was used for the investigations. Tests were conducted using a modified process simulation test (MPST) apparatus at a loading frequency of $20 \mathrm{~Hz}$, with geogrid placed at the subballast-ballast interface and within the ballast. The laboratory experimental results indicate that the geogrid arrests the lateral spreading of ballast, reduces the extent of permanent vertical settlement and minimises the particle breakage under high-frequency cyclic loading. However, the improvement in track performance is directly influenced by the effectiveness of the ballast-geogrid interface. It is shown that the higher the shear strength at the ballast-geogrid interface, the lower is the deformation and degradation of ballast. In addition, the geogrid also reduces the extent of vertical stress in the subgrade soil. These test results highlight the role of geogrid in stabilising the ballast thus encouraging its use as track reinforcement in railway applications.
\end{abstract}

Keywords: geogrid, ballast, lateral spread, vertical settlement, particle breakage, cyclic loading.

\section{Introduction}

The performance of a ballasted railway track is directly dependant on the effective functioning of the ballast layer and the corresponding track deformation and degradation characteristics. However, the large vertical train loads combined with 
relatively small horizontal confining stress leads to the lateral flow of ballast under the cyclic loading conditions [1]. This lateral flow of particles reduces the horizontal residual stresses that confine the ballast, therefore reducing the stability of the track [2]. In the recent times, in an effort to arrest the lateral displacement of particles and hence reduce the track maintenance costs, the rail authorities have resorted to the geogrid reinforcement of ballast. The improvement in track performance due to geogrid occurs because of the particle interlocking. In this view, large-scale cyclic tests are carried out on geogrid-reinforced ballast using the modified process simulation test (MPST) apparatus to establish the benefits of reinforcement on the track performance. Moreover, to establish the role of ballast-geogrid interface shear behaviour on the track performance, the settlement and degradation aspects of geogrid-reinforced ballast are correlated to the ballast-geogrid interface shear strength [3].

\section{Laboratory investigations on geogrid-reinforced ballast}

\subsection{Test apparatus}

The MPST apparatus used in the current study has the plan dimensions of $800 \times 600$ $\mathrm{mm}$ and can accommodate samples measuring $650 \mathrm{~mm}$ in height. The central portion of one of the side walls parallel to sleeper consists of a setup of five independent movable plates (numbered 1 to 5) each measuring $600 \mathrm{~mm}$ in width and $64 \mathrm{~mm}$ in height assembled along the depth (Figure 1a). A small gap of $1 \mathrm{~mm}$ between the adjacent plates ensures the free lateral movement of each individual plate under the applied loading [4]. Server controlled actuators are connected to the movable plates to apply the desired confining pressure (Figure 1b).
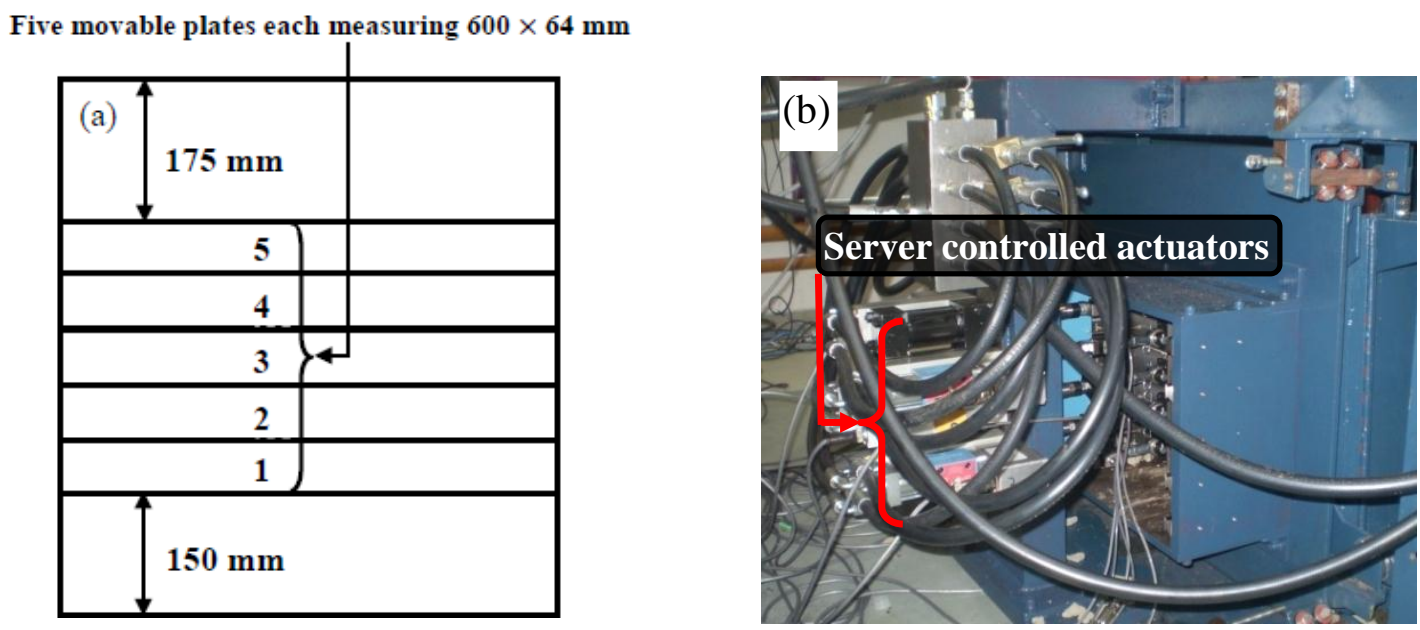

Figure 1: (a) Schematic diagram of the side wall of the MPST apparatus (b) Server controlled actuators used to apply the confining pressure on to the movable plates 


\subsection{Materials and method of testing}

Fresh latite basalt from Bombo quarry, NSW, Australia, with a particle size distribution (PSD) conforming to AS 2758.7 [5] was used in this study (Figure 2). The test specimen comprised of a subballast layer of $150 \mathrm{~mm}$ at the bottom of the test chamber overlain by a $325 \mathrm{~mm}$ thick layer of ballast compacted in three layers to a density of $1550 \mathrm{~kg} / \mathrm{m}^{3}$. An assembly of sleeper (tie) and rail section, and crib ballast up to $150 \mathrm{~mm}$ thick was placed above the load-bearing ballast. Settlement plates were installed at the subballast-ballast interface and at the sleeper-ballast interface to record the settlement upon loading. For reinforced specimens, a layer of geogrid was placed at either (a) $z=0 \mathrm{~mm}$ or (b) $z=65 \mathrm{~mm}$, where $z$ is the distance above the subballast-ballast interface. The physical characteristics and the technical specifications of the geogrids used (labelled G1 to G4) are summarized in Table 1. The specific geogrids used in the study were decided based on the interface efficiency factor $(\alpha)$, defined as the ratio of the ballast-geogrid interface shear strength to the internal shear strength of ballast, as obtained from direct shear testing [3].

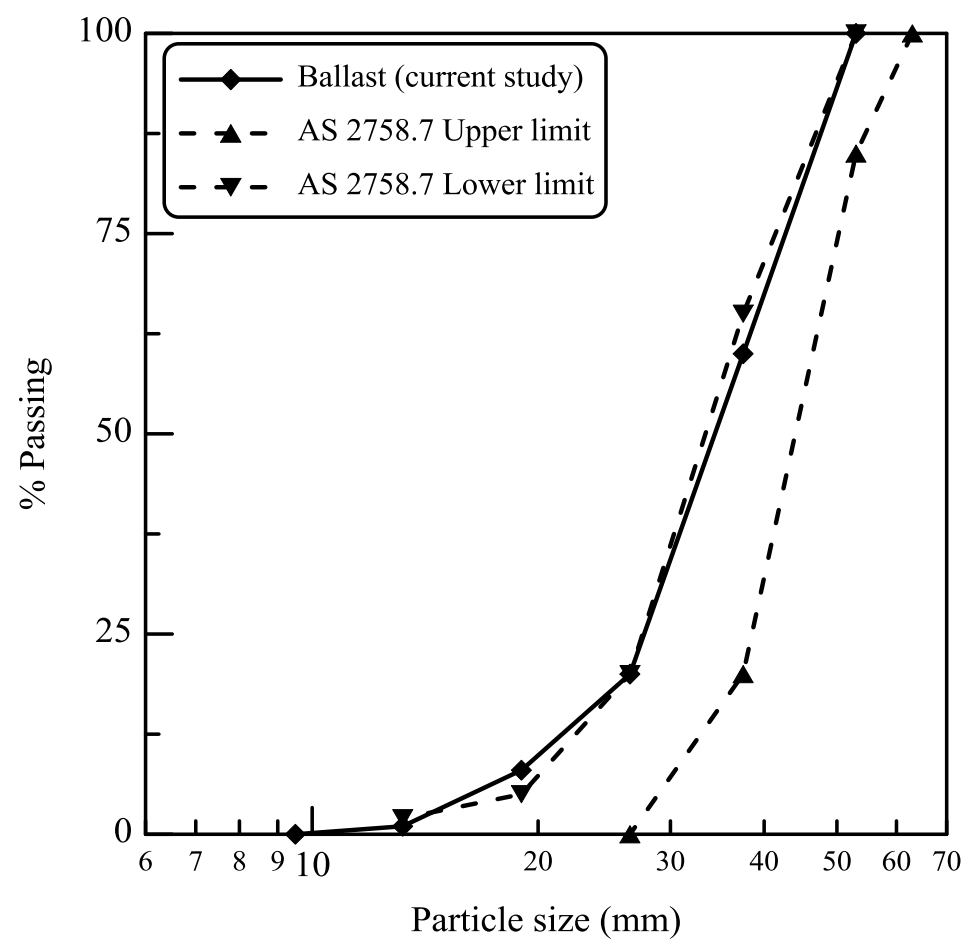

Figure 2: Particle Size Distribution of ballast used for the cyclic tests

A vertical stress of $460 \mathrm{kPa}$ was applied on the sample by means of a dynamic actuator and a lateral pressure of $10 \mathrm{kPa}$ was applied onto the side wall with five movable plates. The other three walls of the test tank were held fixed and only the modified side wall was allowed to move laterally [4]. Tests were conducted at a loading frequency of $20 \mathrm{~Hz}$ (i.e. $146 \mathrm{~km} / \mathrm{h}$ ) and up to 250,000 load cycles. The 
lateral movement of the individual plates was recorded continuously by the potentiometers connected to a data acquisition system. The electronic potentiometers used for recording the lateral movement of the plates were calibrated prior to each test. The tests were halted at selected number of load cycles (i.e. $N=1 ; 100 ; 1000$; $3000 ; 5000 ; 10,000 ; 30,000 ; 50,000 ; 100,000$ and 200,000) to record the readings from the settlement plates. The ballast specimen was sieved at the end of each test to evaluate the change in gradation and to quantify the breakage of particles.

\begin{tabular}{cccccccccc}
\hline $\begin{array}{c}\text { Geogrid } \\
\text { type }\end{array}$ & $\begin{array}{c}\text { Aperture } \\
\text { shape }\end{array}$ & $\begin{array}{c}\text { Aperture } \\
\text { size }(\mathrm{mm})\end{array}$ & $\begin{array}{c}\text { Rib } \\
\text { thickness } \\
(\mathrm{mm})\end{array}$ & $T_{\text {ult }}{ }^{\mathrm{a}}(\mathrm{kN} / \mathrm{m})$ & $\begin{array}{c}J_{\text {sec }}{ }^{\mathrm{b}}(2 \% \\
\text { strain }) \\
(\mathrm{kN} / \mathrm{m})\end{array}$ \\
\cline { 2 - 11 } & & MD & CMD & MD & CMD & MD & CMD & MD & CMD \\
\hline$G 1$ & Square & 38 & 38 & 2.2 & 1.3 & 30 & 30 & 525 & 525 \\
$G 2$ & Triangle & 36 & 36 & 2.0 & 2.0 & 19 & 19 & 230 & 230 \\
$G 3$ & Square & 65 & 65 & 1.7 & 1.5 & 30 & 30 & 550 & 600 \\
$G 4$ & Rectangle & 44 & 42 & 1.0 & 1.0 & 30 & 30 & 500 & 500 \\
\hline
\end{tabular}

Table 1: Physical characteristics and technical specifications of the geogrids used in the study, with ${ }^{\mathrm{a}}$ Ultimate tensile strength (manufacturer supplied values); ${ }^{\mathrm{b}}$ Secant modulus (manufacturer supplied values); MD-Machine direction; CMD-Cross machine direction.

\section{Experimental results and discussion}

\subsection{Lateral spreading of ballast}

Figure 3 shows the variation of lateral displacements in unreinforced and geogridreinforced ballast (G3 placed at $z=65 \mathrm{~mm}$ ) with the number of load cycles $(N)$ determined from the movement of side plates numbered 1-5. It is evident from Figure 3 that the geogrid effectively restrains the lateral flow of ballast in comparison to unreinforced conditions. Figure 3 also depicts the effect of geogrid with distance away from its placement position. The lateral deformations in reinforced ballast at the end of testing as measured from plates 1-5 are 5, 8, 16, 23 and $8 \mathrm{~mm}$ respectively when compared to $18,23,25,22,7.9 \mathrm{~mm}$ in unreinforced ballast. Here, the geogrid is placed at the interface of first and second movable plates (i.e. $65 \mathrm{~mm}$ ), and hence it effectively arrests the lateral deformations in ballast at levels corresponding to plates one and two and partially arrests the ballast movement at the level of plate three. However, the lateral displacements in geogrid-reinforced ballast as measured from plates four and five are almost similar to that of unreinforced ballast. These experimental results highlight that the effect of geogrid decreasing rapidly with distance away from its placement position. 

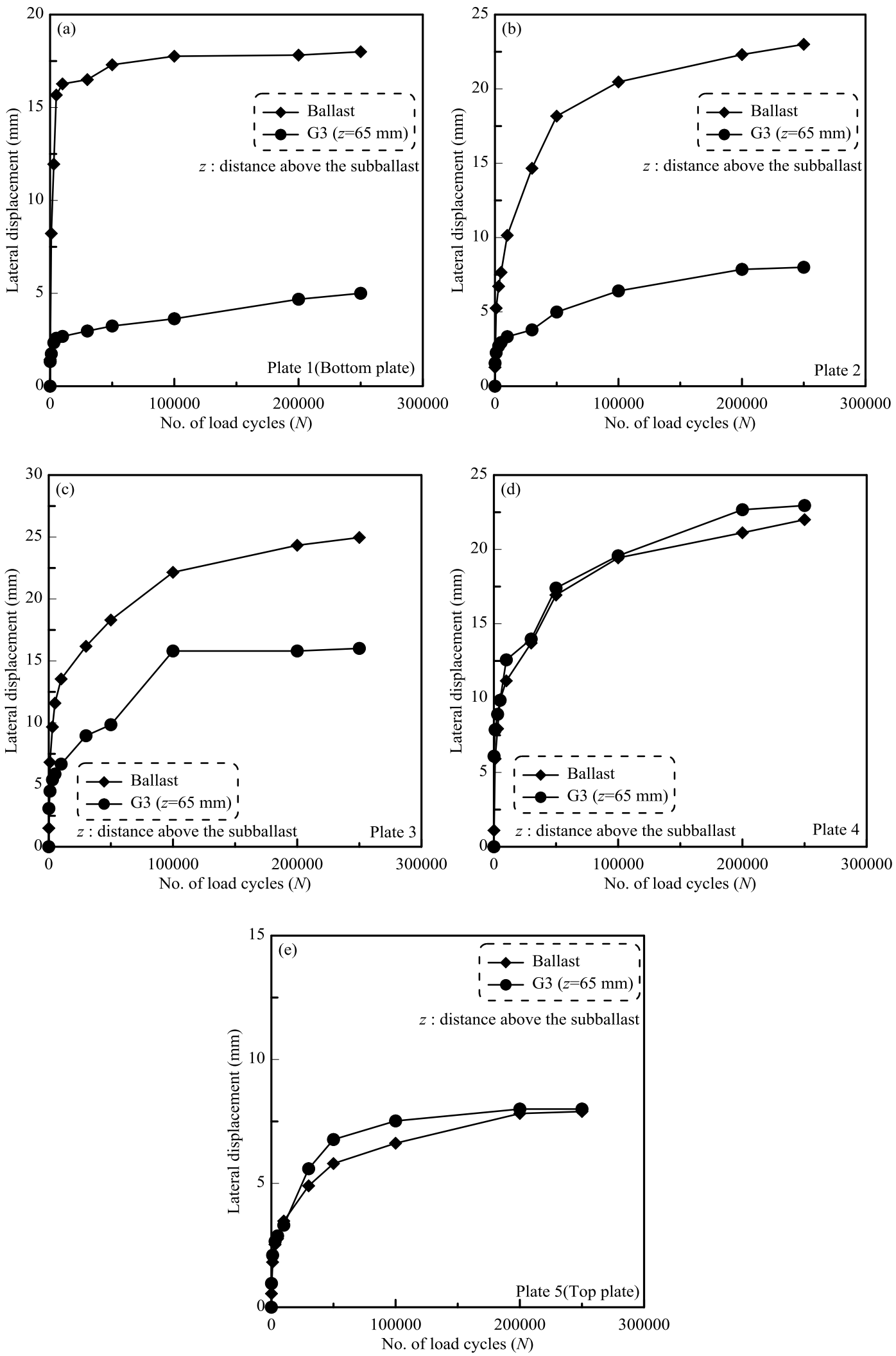

Figure 3: (a)-(e). Lateral displacements in ballast as measured from plates 1 to 5 


\subsection{Vertical settlement and breakage of ballast}

Figure 4 depicts the variation of vertical settlement with the number of load cycles $(N)$ for both unreinforced and geogrid-reinforced ballast. The major portion of vertical settlement takes place during the initial 30,000 load cycles after which the ballast reaches a state of shakedown, for both unreinforced and reinforced conditions (Figure 4). It is seen that the geogrid reinforcement of ballast reduces the extent of vertical settlement, which is in accordance with the results reported by the previous researchers [e.g. 6,7,8]. For instance, the vertical settlement of ballast reinforced with geogrids $\mathrm{G} 1, \mathrm{G} 2, \mathrm{G} 3$ and $\mathrm{G} 4$ placed at $\mathrm{z}=0 \mathrm{~mm}$ are $16.5,19.3,14.7$ and 13.2 $\mathrm{mm}$ respectively, in comparison to a settlement of $23.5 \mathrm{~mm}$ for unreinforced ballast. The geogrid G4 reduces the settlement by $44 \%$ and $58 \%$ in comparison to unreinforced ballast when placed at $\mathrm{z}=0$ and $65 \mathrm{~mm}$. The particle breakage is evaluated in terms of ballast breakage index (BBI) [9] at the end of tests. It is evident that the reinforced ballast undergoes lesser particle breakage in comparison to unreinforced conditions (Table 2). For instance, the breakage of ballast reinforced with geogrid G4 placed at $z=0$ and $65 \mathrm{~mm}$ is about $36 \%$ and $53 \%$ lower than that of unreinforced ballast (BBI=9.89\%). The geogrids $\mathrm{G} 1, \mathrm{G} 3$ and $\mathrm{G} 4$, when placed at $\mathrm{z}=65 \mathrm{~mm}$, reduces the particle breakage to $6 \%, 4.8 \%$ and $4.6 \%$ respectively. It is noticed that a relatively higher reduction in both the settlement and BBI occurs for geogrid (G1, G3 and G4) placed within ballast (i.e. at $\mathrm{z}=65 \mathrm{~mm}$ ), except for geogrid $\mathrm{G} 2$. The reasons for the poor performance of geogrid $\mathrm{G} 2$ at $\mathrm{z}=65 \mathrm{~mm}$ are explained in section 3.5. In a practical sense, reduction in the extent of settlement and breakage of ballast helps preserving the track geometry and particle angularity thus maintaining the requisite track shear strength.

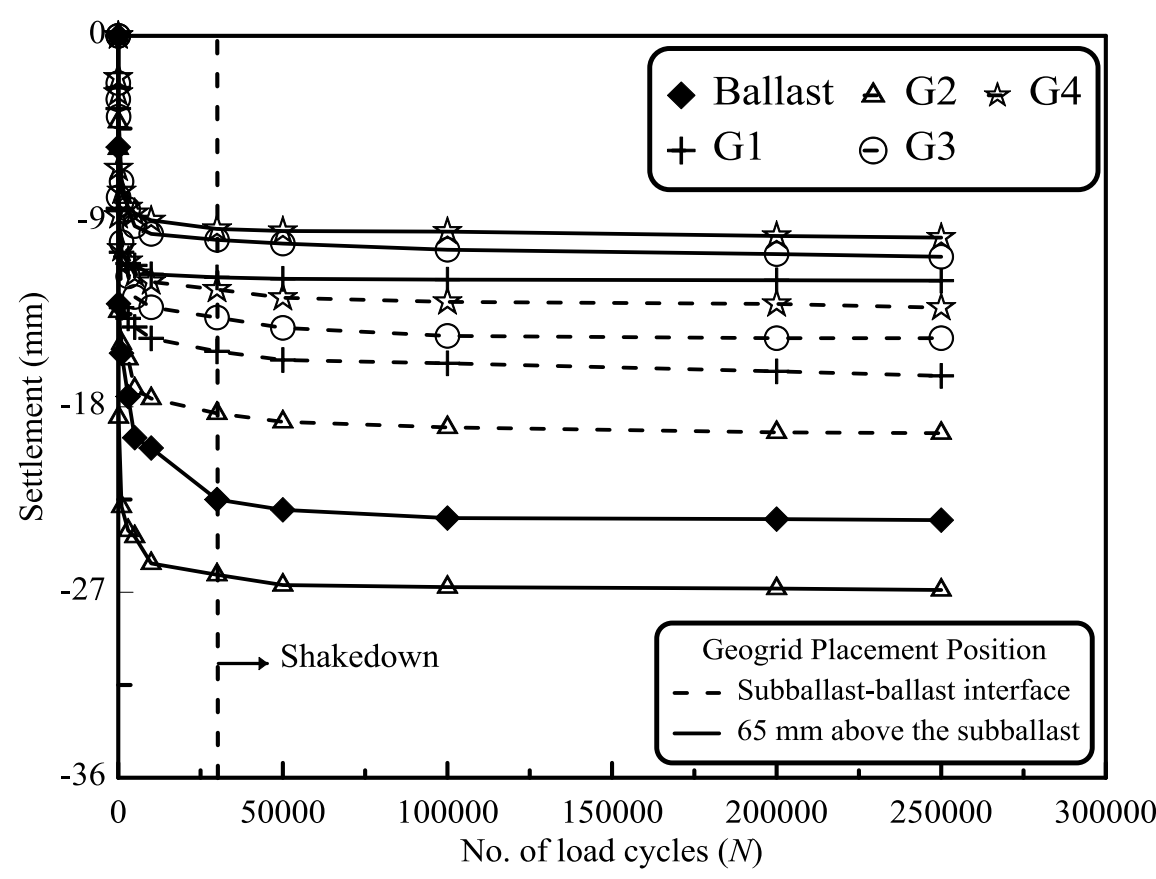

Figure 4: Variation of settlement with number of load cycles (data from [4]) 


\begin{tabular}{c|ccccccccc}
\hline Geogrid type & Ballast & $\mathrm{G}^{*}$ & $\mathrm{G}^{+}$ & $\mathrm{G}^{*}$ & $\mathrm{G}^{+}$ & $\mathrm{G}^{*}$ & $\mathrm{G}^{+}$ & $\mathrm{G} 4^{*}$ & $\mathrm{G}^{+}$ \\
\hline BBI $(\%)$ & 9.89 & 7.80 & 6.00 & 8.90 & 11.00 & 6.50 & 4.80 & 6.30 & 4.60 \\
\hline
\end{tabular}

Table 2: BBI for unreinforced and geogrid-reinforced ballast [4] (Geogrid placement position: * Subballast-ballast interface (i.e. $z=0 \mathrm{~mm}$ ); ${ }^{+} 65 \mathrm{~mm}$ above the subballast (i.e. $z=65 \mathrm{~mm})$ )

\subsection{The variation of volumetric $\left(\varepsilon_{v}\right)$ and shear strain $\left(\varepsilon_{s}\right)$ in ballast with $N$}

The variation of volumetric $\left(\varepsilon_{v}\right)$ and shear strain $\left(\varepsilon_{s}\right)$ with the number of load cycles $(N)$ for unreinforced ballast and that reinforced with various geogrids is shown in Figure 5. In line with the trend seen from the lateral spread and the vertical settlement of ballast (Figures 3 and 4), the volumetric strain increases rapidly during the initial 30,000 load cycles and then remains almost constant. It is observed from Figure 5 that all the ballast samples undergo volume reduction (i.e. cyclic densification) upon cyclic loading. However, the extent of volume reduction is relatively lower for reinforced ballast. Thereby implying that geogrid stabilises the track without causing any significant densification, thus maintaining sufficient voids in ballast that are imperative for the quick drainage of water. For instance, the volumetric strain of ballast reinforced with G3 ( $\mathrm{z}=0$ and $65 \mathrm{~mm})$ is $2.62 \%$ and $1.8 \%$ in comparison to $4.83 \%$ for unreinforced ballast. Similarly, the geogrid-reinforced ballast exhibits reduced shear strain in comparison to unreinforced ballast (Figure 6), which is an indication of enhanced shear strength of ballast due to the reinforcement. For example, the shear strain of ballast reinforced with $\mathrm{G} 3(\mathrm{z}=0$ and $65 \mathrm{~mm})$ is $2.83 \%$ and $2.8 \%$ in comparison to $5.78 \%$ for unreinforced ballast. These experimental observations correlate well with the field study of geosyntheticreinforced ballasted tracks [8].

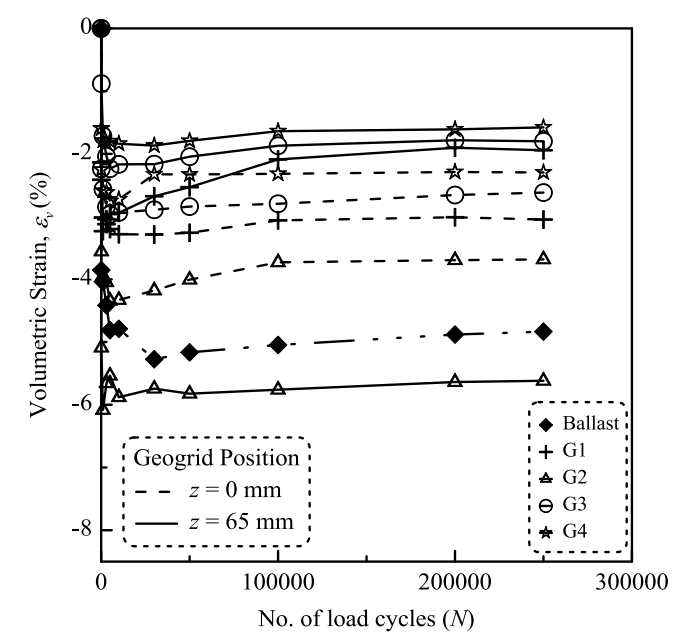

Figure 5: Variation of volumetric strain $\left(\varepsilon_{v}\right)$ with the number of load cycles $N$ 


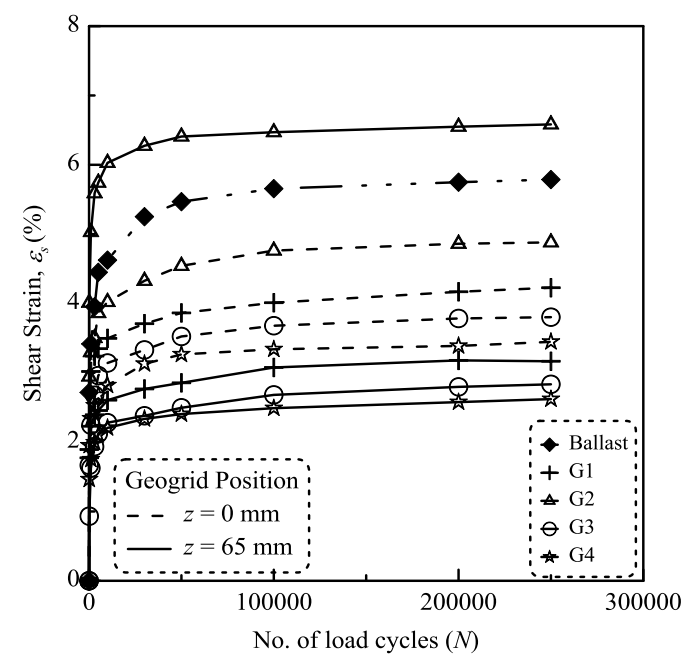

Figure 6: Variation of shear strain $\left(\varepsilon_{s}\right)$ with the number of load cycles $N$

\subsection{Effect of particle breakage on the volumetric and shear strain in ballast}

It is well known that the breakage of sharp angular projections and particle splitting lead to the cyclic densification of ballast and the reduction in its shear strength [e.g. $10,11]$. In this view, the variation of volumetric and shear strains in ballast with respect to BBI is presented in Figures 7 ( $\mathrm{a} \& \mathrm{~b})$. It is evident that both volumetric strain (i.e. cyclic densification) and shear strain increases with the increase in BBI. With the increase in particle breakage (BBI) from $4.6 \%$ to $11.0 \%$ it is seen that the volumetric and the shear strain increases from $1.58 \%$ to $5.6 \%$ and $2.62 \%$ to $6.58 \%$, respectively (Figure 7). The migration of broken fragments into the ballast voids is responsible for the increased densification with the increase in particle breakage. Similarly, the reduced particle angularity with the onset of particle breakage is responsible for the increased shear strain in ballast.

\subsection{The role of interface efficiency factor $(\alpha)$ on the vertical settlement and ballast breakage}

The beneficial effects of geogrid reinforcement stem from the interaction at the ballast-geogrid interface in the form of interlocking of particles within the geogrid apertures [e.g. 3,7,12,13,14,15]. The degree of interaction at soil-geosynthetic interfaces is generally presented in terms of interface efficiency factor $(\alpha)$, the ratio of the soil-geosynthetic interface shear strength to the internal shear strength of soil. While an effective interlocking of particles improves the shear strength at the ballast-geogrid interface, ineffective interlocking can even reduce the shear strength in comparison to the internal shear strength of ballast $[3,16]$. Figure 8 establishes the effect of shear behaviour at the ballast-geogrid interface on the settlement and breakage characteristics of ballast under cyclic loading. Here, the vertical settlement and the ballast breakage data from the current study are plotted with respect to the 
interface efficiency factor $(\alpha)$ of the respective geogrids [3]. It is clear from Figure 8 that both the vertical settlement and the ballast breakage reduce with the increase in $\alpha$. However, the settlement and particle breakage are higher in comparison to unreinforced ballast for $\alpha=0.9$ (i.e. for geogrid G2). The value of $\alpha$ less than unity indicates ineffective interlocking of particles within the geogrid apertures [3] that eventually lead to higher settlement and ballast breakage. The geogrids G1 and G3 with $\alpha=1.09$ and 1.07 undergo a vertical settlement of 11.9, $10.8 \mathrm{~mm}$ and BBI of 6 and $4.8 \%$, respectively. Similarly, the geogrid G4 with highest interface efficiency factor of 1.16 exhibits the lowest settlement and ballast breakage of $9.8 \mathrm{~mm}$ and 4.6\% respectively. These findings imply that the shear behaviour at the ballastgeogrid interface plays an important role on the deformation and degradation response of ballast.
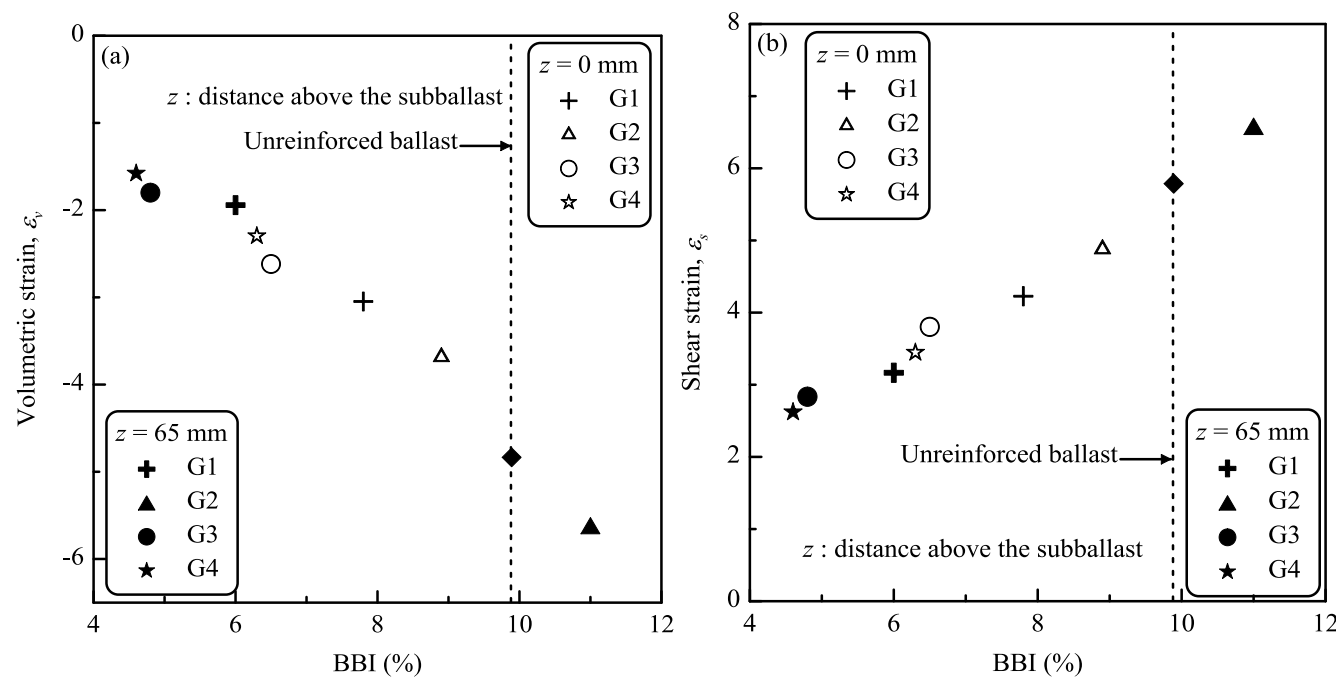

Figure 7: (a) Variation of volumetric strain with BBI and (b) Variation of shear strain with BBI

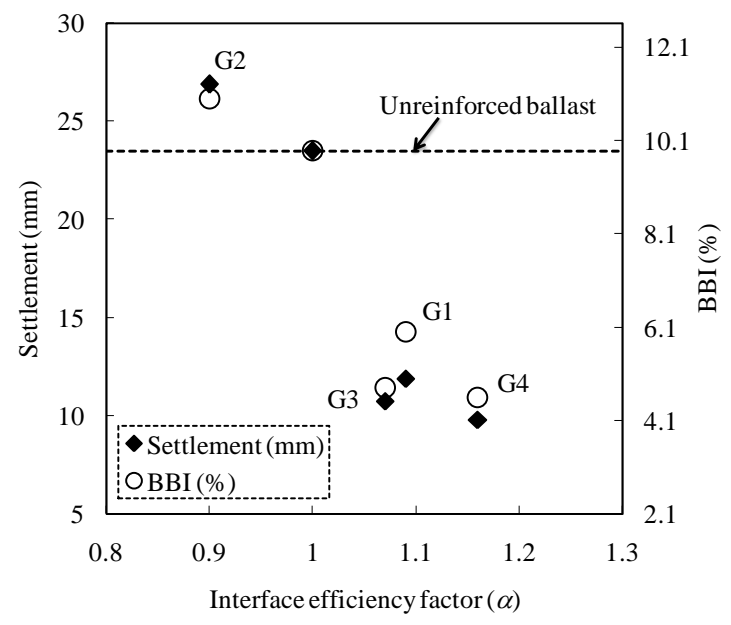

Figure 8: Variation of settlement and ballast breakage with interface efficiency factor $(\alpha)$ 


\subsection{Vertical stress in the subgrade soil}

Two pressure cells were placed in the test chamber to capture the variation of vertical stress along the ballast depth and establish the role of geogrid in reducing the subgrade stresses (i.e. vertical stress at the subballast-ballast interface). One of the pressure cells was placed at the sleeper-ballast interface and the other at the subballast-ballast interface. A significant reduction in the vertical stress $\left(\sigma_{v}\right)$ was observed with depth for both unreinforced and geogrid-reinforced ballast (Table 3). In comparison to an applied vertical stress of $460 \mathrm{kPa}$, unreinforced ballast experiences a stress of $220 \mathrm{kPa}$ at the subballast-ballast interface. The vertical stress at the subballast-ballast interface is further reduced from $220 \mathrm{kPa}$ to 176 and 155 $\mathrm{kPa}$ upon the geogrid reinforcement of ballast. These results signify the role of geogrid in dissipating the applied vertical stresses to an acceptable level in the case of railway tracks to be constructed on soft soils.

\begin{tabular}{l|cc}
\hline \multirow{2}{*}{ Geogrid type } & \multicolumn{2}{|c}{ Vertical stress (kPa) } \\
\cline { 2 - 3 } & $\begin{array}{c}\text { Sleeper-ballast } \\
\text { interface }\end{array}$ & $\begin{array}{c}\text { Subballast-ballast } \\
\text { interface }\end{array}$ \\
\hline Ballast & 460 & 220 \\
$\mathrm{G3}^{*}$ & 460 & 176 \\
$\mathrm{G3}^{+}$ & 460 & 155 \\
\hline
\end{tabular}

Table 3: Vertical stress in unreinforced and geogrid-reinforced ballast [4] (Geogrid placement position: ${ }^{*}$ Subballast-ballast interface (i.e. $z=0 \mathrm{~mm}$ ); ${ }^{+} 65 \mathrm{~mm}$ above the subballast (i.e. $z=65 \mathrm{~mm}$ ))

\section{Conclusions}

Large-scale cyclic tests have been carried out on geogrid-reinforced ballast using the MPST apparatus. It is shown that during cyclic loading, the geogrid reinforcement effectively arrests the lateral strains in ballast. The lateral deformations in ballast reinforced with $\mathrm{G} 3$ (placed at $\mathrm{z}=65 \mathrm{~mm}$ ) at the end of testing as measured from plates $1-5$ are $5,8,16,23$ and $8 \mathrm{~mm}$ respectively when compared to $18,23,25,22$, $7.9 \mathrm{~mm}$ in unreinforced ballast. The geogrid G4 reduces the settlement by $58 \%$ and breakage by $53 \%$ in comparison to unreinforced ballast when placed at $\mathrm{z}=65 \mathrm{~mm}$. It is further demonstrated that the effect of geogrid decreases with vertical distance from its placement position. Moreover, the test results indicate that the reinforced ballast undergoes lower volumetric compression which implies that the geogrid helps maintaining sufficient voids in ballast that are imperative for the quick drainage of water. Furthermore, it is shown that the geogrid reduces the vertical stress at the subballast-ballast interface from $220 \mathrm{kPa}$ to $155 \mathrm{kPa}$ thereby, minimising the risk of foundation failure and the subsequent fouling of ballast. 


\section{Acknowledgement}

The authors would like to thank the CRC for Rail Innovation for funding this research. The assistance of Technical Officers at the Centre of Geomechanics and Railway Engineering, University of Wollongong in the laboratory tests is highly appreciated.

\section{References}

[1] M. Baessler, W. Rucker, "Track settlement due to cyclic loading with low minimum pressure and vibrations", System dynamics and long-term behaviour of railway vehicles, Track and subgrade, Popp, K. and Schiehlen, W., (Editors), Springer, Berlin, 337-356, 2003.

[2] E.T. Selig, J.M. Waters, "Track geotechnology and substructure management", Thomas Telford Services Ltd., London, UK, 1994.

[3] B. Indraratna, Syed K. K. Hussaini, and J.S. Vinod, "On the shear behavior of ballast-geosynthetic interfaces". Geotechnical testing journal, ASTM, 35(2), 305-312 (DOI: 10.1520/GTJ103317), 2012.

[4] B. Indraratna, Syed K. K. Hussaini, and J.S. Vinod, "The lateral displacement response of geogrid-reinforced ballast under cyclic loading", Geotextiles and Geomembranes, 39, 20-29, 2013.

[5] AS 2758.7. Aggregates and Rock for Engineering Purposes, Part 7: Railway Ballast. Standards Association of Australia, NSW, 1997.

[6] M.S. Matharu, "Geogrid cut ballast settlement rate on soft substructures", Railway Gazette International, 150(3), 165-166, 1994.

[7] S.F. Brown, J. Kwan, N.H. Thom, "Identifying the key parameters that influence geogrid reinforcement of railway ballast", Geotextiles and Geomembranes, 25(6), 326-335, 2007.

[8] B. Indraratna, S. Nimbalkar, D. Christie, C. Rujikiatkamjorn, J.S. Vinod, "Field Assessment of the Performance of a Ballasted Rail Track with and without Geosynthetics", Journal of Geotechnical and Geoenvironmental Engineering, 136(7), 907-917, 2010.

[9] B. Indraratna, J. Lackenby, D. Christie, "Effect of confining pressure on the degradation of ballast under cyclic loading", Geotechnique, 55(4), 325-328, 2005.

[10] B. Indraratna, D. Ionescu, and H. D. Christie, "Shear behaviour of railway ballast based on Large Scale Triaxial Testing", Journal of Geotechnical Geoenvironmental Engineering 124(5), 439-449, 1998.

[11] P. K. Thakur, "Cyclic densification of ballast and associated deformation and degradation", Ph.D. thesis, Univ. of Wollongong, Wollongong, NSW, 2011.

[12] J.P. Giroud, and J. Han, "Design Method for Geogrid- Reinforced Unpaved Roads. I: Development of Design Method," Journal of Geotechnical Geoenvironmental Engineering, 130(8), 775-786, 2004.

[13] B. Indraratna, H. Khabbaz, W. Salim, J. Lackenby, and D. Christie, "Ballast Characteristics and the Effects of Geosynthetics on Rail Track Deformation", 
International Conference on Geosynthetics and Geoenvironmental Engineering, ICGGE, Bombay, India, December 8-10, 3-12, 2004.

[14] B. Indraratna, M. A. Shahin, and W. Salim, "Stabilisation of granular media and formation soil using geosynthetics with special reference to railway engineering", Ground Improvement, 11(1), 27-43, 2007.

[15] Syed K. K. Hussaini, B. Indraratna, J. S. Vinod, "Some aspects of the shear behaviour of unreinforced and geosynthetic-reinforced rail ballast", International Conference on Ground Improvement and Ground Control: Transport Infrastructure Development and Natural Hazards Mitigation, (889894). 30th October-2nd November, 2012, Wollongong, Australia, 2012.

[16] Syed K. K. Hussaini, B. Indraratna, J. S. Vinod, "Performance of geosynthetically-reinforced ballast in direct shear conditions", In G. A. Narsilio, A. Arulrajah \& J. Kodikara (Eds.), 11th Australia-New Zealand Conference on Geomechanics: Ground engineering in a Changing World (pp. 1268-1273). Australia: Engineers Australia, 2012. 